日臨外会誌 $61(1), 114-117,2000$

症例

3 年の経過観察がなされた十二指腸球部悪性リンパ腫の 1 例

\author{
鬼石町病院外科 \\ 工藤 通明平澤敏 昭
}

手術まで 3 年間の経過がある十二指腸原発恶性りンパ腫の 1 例を経験した．症例は70 歳の男性. 食欲不振を主訴として入院. 1994年 9 月, 上部消化管内視鏡検查で, 十二指 腸球部に隆起性病変を認め, malignant lymphoma, diffuse lymphoma, small cell type の診断．その後, 本人受診しなかったが，1997年 8 月，胃検診にて胃前庭部の変形を指 摘され, 再び内視鏡を施行, 生検で malignant lymphoma の診断であり, 腫場径も約 2 倍になっていた，幽門側胃切除術施行．十二指腸球部前壁の 2 型腫場 $(3.0 \times 2.5 \mathrm{~cm}) て ゙$, 病理組織診断は, low grade lymphoma of mucosa associated lymphoid tissue で, 免 疫組織学的染色により $\mathrm{B}$ リンパ球系細胞の増殖が確認された. 術後, VEPA 化学療法を 計 8 回行った. 1 年 6 力月後の現在経過は良好で, 外来通院中である.

索引用語：十二指腸覀性リンパ腫, B 細胞悪性リンパ腫, MALT

はじめに

消化管発生の悪性リンパ腫は, リンパ節外性のリン パ腫に属し, 胃原発の報告例が最も多く, 次いで小腸, 大腸の順で，さらに，十二指腸原発のものはきわめて 稀である.また，消化管原発のものは，全身のリンパ 節に発生するものよりも, 症状の発現が遅く, 手術的 治療が行われることは少ない.文献的には本邦報告例 は64例であった。

われわれは診断から 3 年を経て手術した十二指腸球 部悪性リンパ腫の 1 例を報告する。

症例

患者：70歳, 男性.

主訴：食欲不振。

既往歴：1996年 3 月より梼尿病. 1996年 5 月の脳梗 塞により, 軽度右半身麻痺がある.

現病憷：1994年 9 月，心窝部痛を主訴に，外来を訪 れ上部消化管内視鏡検查を施行した。十二指腸球部前 壁に径 $2 \mathrm{~cm}$ 弱の限局隆起性病変を認めた（図 1 ). 生 検では malignant lymphoma, diffuse lymphoma, small cell type の診断であった. 外科的加療を勧める も本人が拒否し，そのまま外来で経過観察を行った。 さらに，1996年 5 月，脳梗塞のため当院内科に 1 力月 間入院したが，この時も精查ならびに手術を拒否し，

1999年 6 月 24 日受付 1999 年11月 2 日採用
その後も外来通院を続けていた.

1997年 7 月，住民検診の胃の造影検查にて，胃前庭 部の変形を指摘され, 当院を受診. 食欲不振, 体重減 少も認められたため, 十二指腸原発悪性リンパ腫の進 展によるものと診断し，9月16日当科へ入院となった。

入院時現症：体格中等度, 栄養やや不良, 眼瞼結膜 に貧血，眼球結膜に黄㾝を認めず，心肺に異常なし. 腹部は平坦, 右上腹部に小鵎卵大の可動性のある柔ら かい腫瘤を触知したが，同部に圧痛はなかった。肝お よび脾は触知されなかった。表在リンパ節も触知しな かった。

入院時検査成績: 血液検查で白血球数は, $14,900 て ゙$, 分画ではリンパ球数が70\%と増加していた.また,一

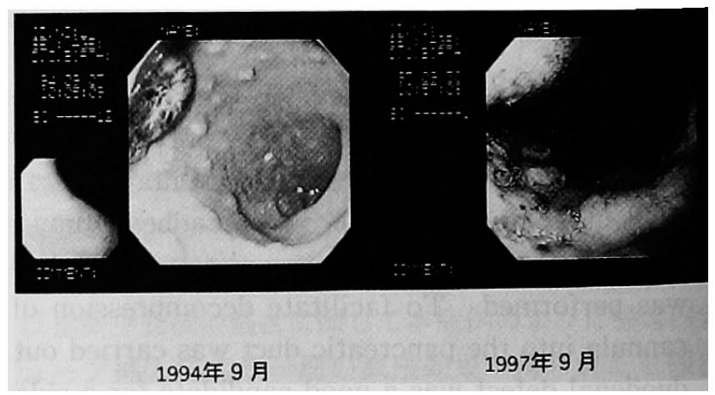

図 1 内視鏡検査：1994年 9 月, 十二指腸球部には直径約 $2 \mathrm{~cm}$ の限局性腫演と周囲に小隆起が多発している. 1997 年 9 月, 腫湯は約 $3 \mathrm{~cm}$ で, 周囲の小隆起も増大している. 
部に幼若なりンパ球を認めた。骨髄穿刺榆査でも，リ ンパ球数は $21.0 \%$ と正常笎囲内であったが, 核異型を 伴う小型リンパ球の增生を認めた。血液生化学検査, 腫瘍マーカー，検尿娭査などでは異常はなかった。ま た，免疫学的検查として，免疫グロブリン分画では， $\operatorname{IgG}, \operatorname{Ig} A, \operatorname{Ig} M$ は全て正常範囲内であった. 白血病・ リンパ腫解析検查である CD (cluster of differentiation）45ケーテイングでは，Bリンパ球の分化抗原 (CD19，CD20)が認められ，B リンパ球由来と診断さ れた.

入院時の胸部単純 X線検査では, 肺野の異常影, 繸 隔リンパ節の腫大は認めなかった．腹部単純 $\mathrm{X}$ 線椧査 も異常はなかった。

低緊張性十二指腸造影検査：十二指腸球部に, 直径 $3 \mathrm{~cm}$ 表面不整な限局隆起型の病変を認めた（図 2 ）.

上部消化管内視鏡検查：十二指腸球部に中心部がや や陥凹した不整な隆起性病変を認めた（図 1)，3 年前 の所見と比較すると，腫瘤およびその周囲の多発した 小さい隆起性病変とも増大していた，腫瘤の病理組織 学的診断は,びまん性に異型りンパ球の浸潤，增殖を 認める malignant lymphoma の診断で, 周囲の小さい 隆起性病変は, 軽度の異型をもつリンパ球の浸潤であ った。またここょりも肛門側への内視鏡の通過は容 易であり, 粘膜面の異常は十二指腸下行脚までに限局 していた. 胃十二指腸組織の Helicobacter pylori 感染 は陰性であった，食道，胃には異常を認めなかった。

腹部 CT 検査（9 月18日）：十二指腸球部内に $3 \times$ $3.5 \mathrm{~cm}$ の限局性腫瘤を認め, 十二指腸周囲への浸潤は なかった。また，周囲の所属りンパ節の腫大が確認さ れた。9月22日の ERCP 検查では, 胆管や十二指腸乳 頭の異常は認められなかった。

以上の検査結果から，十二指腸球部原発の悪性リン

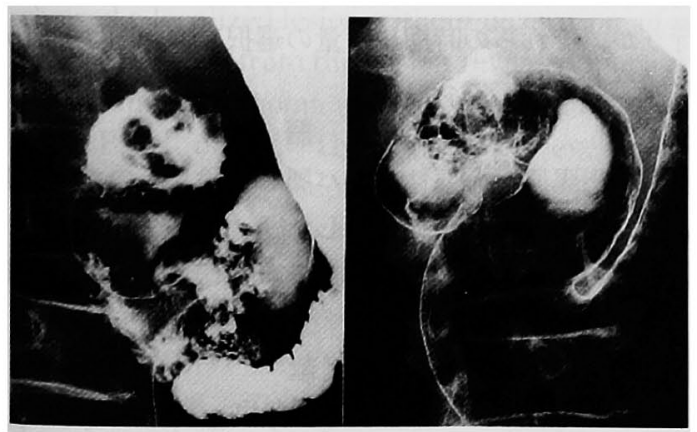

图 2 上部消化管造影：十二指腸球部の前壁に表面が多 結節状の限局性腫瘍を認める。
パ腫と診断し，1997年10月 7 日，開腹手術を行った。 手術所見 : 上腹部正中切開にて開腹した.腹腔内に, 腹水の貯留, 腹膜播腫, 肝転移などはなく, また, 肝 脾腫なども認めなかった。腫咟は, 限局隆起型 $3.0 \times 2.5$ $\mathrm{cm}$ で, 十二指腸球部前壁に存在し, 腫㿇の周囲臟器へ の浸潤は認められず，漿膜面の変化も認められなかっ た。胃所属りンパ節は，『胃癌取扱い規約』で1) 5 番と 6 番が $1 \mathrm{~cm}$ 程度に軽度腫大し，また 13 番も小豆大に 腫大し転移が疑われた。

大動脈周囲リンパ節の腫大は認められなかったが, 小腸間膜に大豆大のリンパ節が散在していた。腫場緑 より $1 \mathrm{~cm}$ 肛門側を切離線として, 幽門側胃切除術, D2 リンパ節郭清と13番リンパ節の生検を行い, Billroth 1 法で再建した.

摘出標本：十二指腸球部前壁の $3.0 \times 2.5 \mathrm{~cm}$ の 2 型 の腫瘍で，その周囲にも小結節が散在していた．腫瘍 割面像を示す（図 3 )。

病理組織学的所見 : maligant lymphoma, diffuse lymphoma, small cell typeであった. ホルマリン固 定パラフィン切片における免疫組織学的所見では, 腫 瘍細胞は LCA 染色, SL-26染色, MB- 1 染色に陽性で あり，また UCHL- 1 および MT- 1 染色に陰性で B リンパ球系細胞の增殖と考元られた（図 4$)$.

腫場を中心に存在する多数の結節は，いずれも腫場 浸潤であり, lymphoid epithelial lesionもみられた。 表層腺管は, 消失傾向であり, MALT (mucosal associated lymphoid tissue) の所見であった。リンパ節 は，第 2 群までと13番リンパ節に転移を認めた。

骨髄穿刺検査でも，骨髄への転移が考えられた，以 上の結果から, Naqviらの消化管悪性リンパ腫の

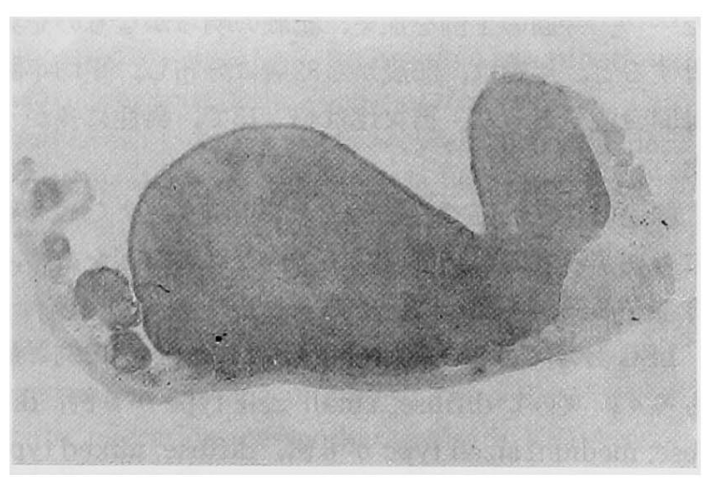

図 3 割面ルーペ像：腫煌は $3.0 \times 2.5 \mathrm{~cm}$ 大の病変を形 成しており, 浸達度は pmで, 周囲への浸潤は認められ ない（右が幽門輪，H.E.染色， $\times 10 ）$. 


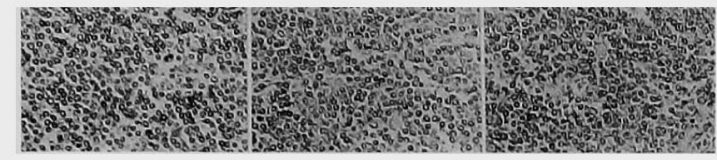

図 4 病理組織像：軽度の異型を保つリンパ球が存在す る(左：LCA 染色, 中央：SL-26染色，右：MB-1染 色, $\times 100)$.

stage 分類 ${ }^{2} に$ 従い，本例を骨髄転移を認める stage IV と診断した.

術後経過：術後経過は順調であった。術後 4 週目よ りサイクロフォスファミド $600 \mathrm{mg}$, アドリアマイシン $40 \mathrm{mg}$, ビンクリスチン $2 \mathrm{mg}$ を 1 日点滴静注, さらに プロドニゾロン $40 \mathrm{mg}$ を 5 日間経口投与する VEPA 化学療法を, 1997年12月 1 日より1998年 3 月17日まで の間に, 計 8 クール行った.

4 月 20 日退院となり, 約 1 年半後の現在外来通院経 過観察中である.

\section{考察}

覀性リンパ腫は発生部位により,リンパ節性とリン パ節外性に分けられる.リンパ節外性悪性リンパ腫は, 鼻腔およびWaldeyer 咽頭輪のものが多く約半数を占 め, 次いで消化管より発生するものが約 $20 \%$ を占めて いる.

消化管の発生部位では，胃が最も多く(約55\%)，次 いで, 小腸（約20\%）, 大腸（約15\%）の順である3). さらに，小腸原発悪性リンパ腫は，回腸が多く，口側 に向かうに従い減少する. Mercuse ら゙によると, 小腸 の悪性リンパ腫192例のうち十二指腸原発のものは 9 例（4.7\%）であり，稀なものである. 本邦報告例は， 朝倉5の報告以来検索し得た限りでは64例であっ $た^{6)-17)}$. 今回の 1 例を加え, 記載の明らかなものを集 計すると, 年齢は, 23歳から82歳に分布し, 平均年齢 は54.1歳であった。男女比は43：15で, 男性に多かっ た.

腫瘍の存在部位でみると，十二指腸 1 部または 2 部 に存在するものが46例（72.6\%）とほとんどを占め, 3 部が 3 例, 4 部は 2 例であった.

LSG 分類では, diffuse, large cell type が10例と最 も多く, 次いで diffuse, small cell type が 6 例, diffese, medium sized type $か$ 6 例, diffuse, mixed type が 5 例などであった。

以前術前診断が難しいとされた時期もあったが, 過 去10年間では13例中12例が術前に診断されており，診
断率も向上している.

胃の悪性リンパ腫の切除率は70～80\%と高く，早期 の症例の極めて良好な治療成績が報じられているのに 比べ，小腸および大腸における悪性リンパ腫の治療成 績は不良で, 特に十二指腸原発のものは予後は極めて 恶い18). その原因として，膵への浸潤が容易であるこ と, 総胆管浸潤例では閉塞性黄疸をきたし全身状態の 悪化があること，また発見が遅れた進行症例では手術 侵襲が過大となるためといわれてきた。しかし，最近 では早期猃断がなされることも多くなり，過去 10 年間 の症例に限ると, 13例中, 膵頭十二指腸切除術が 7 例, 胃切除術が 1 例, 試験開腹術が 1 例, 不明や化学療法 などが 4 例と切除可能例が増加している.

また，悪性リンパ腫は，放射線に対する感受性が高 いため, 切除不能例および再発防止の手段として, さ らに局所の治療として放射線療法が有効であるとの報 告は多い. 多剤併用した化学療法の効果は著しく, CHOP, VEMP, VEPA 療法などが行われている.い ずれにしろ, 十二指腸悪性リンパ腫に対しては, 集学 的治療が必要であり ${ }^{18)}$, 化学療法, 放射線療法は, 十分 な知識を持った医師が合併症に注意して行う必要があ る。

近年, MALToma と Helicobacter pylori 感染の関 係が研究され，除菌によって粘膜面の病変が軽微とな る，腫崵細胞が陰性化すると報告されている ${ }^{16)}$. H.P. 感染有無の確認と, 陽性であれば菌の除菌も必要と考 えられている.

本邦報告例では，B リンパ球由来のものは稀で 3 例 のみであった，血液検査からリンパ球の分類が可能で ある現在, リンパ球由来を検索することが重要である ことはいうまでもない.

今後は, 各症例ごとに病態と進行度を考慮して, 手 術, 放射線療法および化学療法を組み合わせ, 治療を 行うが, それらの時期や用量の選択には詳細な検討が 必要であると考える。

結 語

十二指腸原発の悪性リンパ腫を経験したので，若干 の文献的考察を加えて報告した.

なお本論文の要旨は, 第248回日本消化器病学会関東支部 例会において発表した.

\section{文 献}

1）胃癌研究会編：胃癌取扱い規約. 改訂第 12 版, 金 原出版, 東京, 1993

2) Naqvi MS, Burrows L, Kark AE: Lymphoma 
of the gastrointestinal tract. Ann Surg 170:221 $-231,1969$

3）高木國夫：消化管の悪性リンパ腫.内科 60 ： 1258-1265, 1987

4) Marcuse $M$, Stout $P$ : Primary lymphosarcoma of the small intestine. Cancer $3: 459-474,1950$

5）朝倉義男: 十二指腸空腸細網肉腫の 1 例. 臨消 $5: 51-54,1957$

6）貝沼 修, 原 壮, 谷口徹志他：十二指腸恶性 リンパ腫の 1 例. 日消外会誌 $22: 1875-1878$, 1989

7）蔡元 奎, 馬場信雄, 西村一郎他：十二指腸原発 悪性リンパ腫の 1 例. 日消外会誌 $22 ： 2713-$ 2716,1989

8）中川国利, 桃野 哲, 佐々木陽平他：十二指腸悪 性リンパ尰の 1 例。外科 $52: 1058-1060 ， 1990$

9）酒井浩一, 猪口 寛, 瑇手博義他: 十二指腸狭窄 をきたした悪性リンパ腫の 1 例. 日臨外医会誌 $51: 2473-2477,1990$

10）奥野哲二，石木邦治，木曾尊彦他：十二指腸球部 悪性リンパ車の 1 例. 広島医 $43: 1976-1979$, 1990

11）村田厚夫，小川道雄，藤原義之他：十二指腸原発
悪性リンパ腫の 1 切除例. 消外 $14: 349-355$, 1991

12）小池竜司, 浅田 学, 大西洋英他: 十二指腸原発 $\mathrm{T}$ 細胞性悪性リンパ腫の 1 例. 日消病会誌 88 ： 2883-2886, 1991

13）吉田勝俊, 宮内倉之助, 藤本 章他: 十二指腸原 発悪性リンパ腫の 1 例.消外 $15: 511-515,1992$

14）朝原正京, 那須正道, 出射由香他：小腸ファイパ ースコープにて診断しえた十二指腸水平部原発悪 性リンパ腫の 1 例. Gastroenterol Endosc 35: 1071-1079, 1993

15）保谷芳行, 又井一雄, 織田 豊他：十二指腸原発 悪性リンパ腫の 1 例. 日臨外医会誌 $58: 1523-$ 1526, 1997

16）菅原 元，藤岡 進，加藤健司 他：閉塞性黄疸を 認めた十二指腸悪性リンパ腫の 1 例. 日消外会誌 $32: 1022-1026,1999$

17）紀藤 毅，小寺泰弘，山村義孝他：胃悪性リンパ 腫の治療方針。日消外会誌 $31 ： 9-14,1998$

18) Loehr WJ, Mujahid Z, Zahn FD, et al : Primary lymphoma of the gastrointestinal tract, A review of 100 cases. Ann Surg $170: 232-238$, 1969

\title{
A CASE OF MALIGNANT LYMPHOMA IN THE DUODENAL BULB WITH A 3-YEAR INTERVAL FROM THE DETECTION TO OPERATION
}

\author{
Michiaki KUDO and Toshiaki HIRASAWA \\ Department of Surgery, Onishi Town Hospital
}

We experienced a case of malignant lymphoma of the duodenum with a 3 year interval from the detection to operation.

A 70-year-old man with a past history of diabetes mellitus and brain infarction was admitted to the our hospital because of appetite loss in September 1994. The laboratory findings pointed out an increased number of white blood cells, and bone marrow analysis revealed atypical cell. Endoscopic examinations showed a localized lesion without ulceration, of which surface was seen in the duodenal first portion. The specimen taken from this lesion revealed moderately infilteration of atypical lymphocytes, suspected non -Hodgkin's lymphoma (diffuse, small cell type), and immunohistological study revealed that tumor cells were B-cell origin. The patient, however, withdrew the treatment. In August 1997, the patient was readmitted to the hospital because he was pointed out the deformity of the pyloric antrum at mass screening for gastric cancer. With endoscopy and biopsy, malignant lymphoma was diagnosed and the tumor diameter became double. Operation was performed, and an elevated tumor was seen at the first portion of the duodenum. Furthermore, metastases were seen in the lymph nodes. On a histological study, the preoperative diagnosis was confirmed. After the operation, chemotherapy with VEPA was started. The patient is doing well for the 18 months following the operation. Primary malignant lymphoma in the duodenum is rare in Japan, only 64 cases have been reported in the literature. 